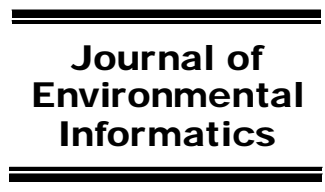

www.iseis.org/jei

\title{
Sediment Flux and Its Environmental Implications
}

\author{
J. Józsa ${ }^{1}$, G. Kiely ${ }^{2}$ and A. G. L. Borthwick ${ }^{3, *}$ \\ ${ }^{1}$ Department of Hydraulic and Water Resources Engineering and MTA-BME Water Management Research Group, Budapest University of \\ Technology and Economics, Budapest H-1521, Hungary \\ ${ }^{2}$ Centre for Hydrology, Micrometeorology and Climate Change, Department of Civil and Environmental Engineering, Environmental Research \\ Institute, University College Cork, Cork, Ireland \\ ${ }^{3}$ School of Engineering, The University of Edinburgh, The King's Buildings, Edinburgh EH9 3JL, UK
}

Received 27 October 2014; revised 10 December 2014; accepted 16 December 2014; published online December 20, 2014

\begin{abstract}
Sediment transport in fluvial systems is a key driver of basin-wide global soil loss, river sedimentation, and the movement and transformation of organic, inorganic, and nutrient materials, all of which can contribute to severe eco-environmental degradation. Since the late 1800 s, much research effort has focused on the physics of sediment entrainment, transport, and deposition by river flows. This paper reviews ongoing research aimed at considering the simultaneous physical, chemical and biological processes that characterize riverine sediment flux. Four related issues are considered: riverine sediment flux; soil erosion and chemical transport; fluxes of dissolved organic carbon; and sediment-induced $\mathrm{CO}_{2}$ emission/sequestration. Modelling of sediment flux has moved beyond empirical and statistical approaches to that of a generalized form of the universal integral solution of the basic flux equation, which is now anticipated to lead to a wide range of applications. Whereas soil erosion and riverine chemical transport are now known to cause soil degradation and reduced water quality, limited progress has been made to date on the quantification of erosion rates. As soils erode, $\mathrm{CO}_{2}$ is emitted at erosion and transport sites and sequestered at deposition sites, the net effect being carbon sequestration. However, the rates of $\mathrm{CO}_{2}$ emission/sequestration vary widely, owing to the large spatial variations in soil type, land-slope, rainfall intensity, etc. It is now well established that dissolved organic carbon (DOC) concentrations and fluxes have been increasing over the past two decades, due to reduced atmospheric sulphur concentration, climate warming, and changes in precipitation patterns. The research discussed herein provides insight into the interaction between sediment and multiple material substances, leading to a better understanding of fluvial river ecosystems, which is essential for maintaining river health.
\end{abstract}

Keywords: sediment flux, soil erosion, environmental implication, chemical transport, dissolved organic carbon, $\mathrm{CO}_{2}$ flux

\section{Preamble}

Conventionally, the main surface material transport processes associated with sediment movement in a river basin may be categorized as runoff and sediment yield, soil erosion and nutrient loss, and river geomorphological evolution. The material transport processes tend to be considered by hydrologists, sedimentologists, hydraulic engineers, agronomists, ecologists, and environmentalists (Kisi et al., 2013; Van Rijn et al., 2013; Miller et al., 2014), whereas the geomorphic evolution of a watershed is the primary concern of geomorphologists (Provansal et al., 2014; Toone et al., 2014). In recent years, the environmental effects of sediment movement through a river basin have been investigated in terms of variations in natural organic matter, nutrients, and contaminants in water-sediment two-phase systems, extending to multiphase systems of water-sediment-carbon, water-sediment-nitrogen, and water-sediment-phosphorous, owing to the considerable

${ }^{*}$ Corresponding author. Tel.: +44 131 6505588; fax: +44 1316506554.

E-mail address: alistair.borthwick@ed.ac.uk (A. G. L. Borthwick).

ISSN: 1726-2135 print/1684-8799 online

(C) 2014 ISEIS All rights reserved. doi: 10.3808/jei.201400287 annual losses of carbon, total nitrogen (TN) and total phosphorous (TP) to surface waters (Panagopoulos et al., 2007; Mora et al., 2014). At the time of writing, there is an increasing research focus on the migration and transformation of the organic and inorganic forms of carbon, largely because of their sensitivity to global environmental change (Raymond and Bauer, 2001; Galy et al., 2007). Obviously, a systematic description of the coupled processes of material transport in multiphase river systems is essential if we are to assess accurately the environmental impact of sediment transport.

The aim of this review paper is to provide an overview of the present state of knowledge of sediment flux and its environmental implications, thereby achieving a better understanding of river systems and their sustainability. The conventional focus has been on sediment generated from soil erosion in a basin with associated chemicals absorbed onto solids or dissolved in water. However, nutrients have become of major concern to environmentalists, while carbon is the primary issue in environmental, ecological and climatic study areas concerned with global change, in terms of both dissolved organic carbon and gaseous $\mathrm{CO}_{2}$ flux. Hence, this paper discusses four inter-related issues closely related to sediment transport processes, including sediment flux, soil erosion and chemical transport, dissolved organic carbon, and sediment- 
induced $\mathrm{CO}_{2}$ emission and sequestration. This approach has the advantage of treating the different facets of sediment transport in the spirit of a generalized integral form of the basic flux equation, which opens up a wide vista of future applications in earth science.

\section{Sediment Flux}

Water and sediment are the main carriers of various materials in river basins. The motion of the water-sediment mixture can have severe environmental consequences, owing to the sediment load carrying materials such as natural organic matter, nutrients and contaminants (Iwata et al., 2013; Thouvenot et al., 2007). Many theories have been proposed to describe the characteristics of sediment transport (Abad et al., 2008; Ganju and Schoellhamer et al., 2009; Zhang et al., 2013). Of these, the most frequently used theories are based on continuum concepts. The continuum assumption, which has proved very successful in representing liquid-gas motions, intuitively appears insufficient to describe motions of discrete solid particles in two-phase flows. Meanwhile, stochastic models can be used to model the motions of individual particles in a fluid. However, stochastic models assume that the random jump of each particle is independent and fits a Markov process, and so can only be applied to homogeneous turbulent flows and do not properly describe the interactions between solid particles. More sophisticated studies adopt a combined approach for describing solid-liquid systems whereby the liquid phase is modeled by means of the continuum concept and the solid phase using kinetic theory, with proper consideration taken of the interactions between the two phases.

The suspended sediment transport rate is usually calculated by integrating the product of the sediment velocity and concentration over the depth. In uniform flow in a simplified open channel, suspended sediment transport at equilibrium is reasonably well described by means of standard vertical profiles for the flow velocity and the concentration of suspended sediment. For engineering purposes, the velocity profile may be satisfactorily represented by a logarithmic distribution, provided the flow contains low concentrations of sediment (i.e. is dilute). However, this may not be the case for hyperconcentrated sediment-laden flow. Alternatively, the vertical sediment profile could be approximated by the well-established formula derived by Rouse (1937) from the principle of mass conservation. Due to the limitations of the Rouse formula, considerable research effort has gone into improved modeling of the concentration distribution of suspended sediment. This has led to diffusion, energy, mixture, similarity, stochastic, and two-phase flow theories, from which various formulas have been developed (see e.g. Rouse, 1937; Knapp, 1938; Bakhmeteff and Allan, 1946; Bagnold, 1962; Ananian and Gerbashian, 1965; Matalas, 1970; Drew, 1975; McTigue, 1981; Mendoza and Zhou, 1995). One of the most exciting advances ma-de in the past few decades was by Ni and Wang (1991), who proved that a similar differential equation would be finally derived no matter which of the aforementioned theories was selected, which directly led to a generalized formula as an universal integral solution of the basic equation. $\mathrm{Ni}$ and his colleagues also demonstrated that most well-known formulas such as those proposed by Rouse (1937), Lane and Kalinske (1941), Hunt (1954), Ananian and Gerbashian (1965), Zagustin (1968), Laursen (1980), and Itakura and Kishi (1980) were merely special cases of the generalized formula under different conditions. This stimulated further studies which are still on-going (Cheng et al., 2013; Kundu and Ghoshal, 2014), the aim being to extend the general expression to an increasingly wide range of applicability.

Given that the suspended sediment transport rate is determined by the integral product of the sediment velocity and concentration over the flow depth, a plethora of formulas have been derived from different mathematical expressions for velocity and concentration profiles (Buyevich, 1990; Rasteiro et al., 1993; Davis and Gecol, 1994; Cheung et al., 1996; Xue and Sun, 2003; Deng et al., 2008; Bai and Duan, 2014). However, various further aspects must also be considered when calculating sediment transport in unsteady flow, in a nonstraight channel or in a human disturbed river system (Lenzi and Marchi, 2000; Sammori et al., 2004; Francke et al., 2008; Marttila and Kløve, 2010; Gao and Puckett, 2012; Kabir et al., 2014). For example, although sediment-discharge hysteresis loops have been much analyzed in order to facilitate a better understanding of sediment transport processes, it remains unclear how to characterize accurately the hysteresis using indices (Aich et al., 2014). Moreover, to evaluate anthropogenic changes to river channels, full account must be taken of discontinuities in flow and sediment transport, and their effect on primary geomorphic parameters such as the active channel width, bed slope, and sediment grain size.

River water and sediment fluxes are closely related to runoff and sediment yield in a river basin. However, the descriptions of soil erosion used nowadays mainly derive from statistical and physical models based on causality. As a core activity of global change research, e.g. within the IGBP and IHDP programs, assessments of water and soil loss are made at three spatial scales; namely, hillside, watershed, and regional scales. Statistical models focus on the establishment of empirical relationships between water, soil loss, and various influencing factors; of such models, the most widely used include the universal soil loss equation (USLE) (Wischmeier, 1976) and the revised universal soil loss equation (RUSLE) (Renard et al., 1991). Physical models are usually based on deterministic theories for hydrodynamics and sediment transport, which are used to predict runoff and sediment yield in small basins. Examples of physical-deterministic models include CREAMS (Chemicals, Runoff and Erosion from Agrcuiltural Management Systems), GLEAMS (Groundwater Loading Effect of Agricultural Management Systems), CSEP (Climate Index for Soil Erosion Potential), EPIC (Erosion-Productivity Impact Calculator), ANSWERS (Areal Nonpoint Source Watershed Environment Response Simulation), AGNPS (Agricultural Nonpoint Pollution Source), KINEROS (Kinematic Runoff and Erosion Model), MEDALUS (Mediterranean Desertification and Land Use), EUROSEM (European Soil Erosion Model), WEPP (Water Erosion Prediction Pro- 
ject) (Laflen et al., 1991) and LISEM (Limburg Soil Erosion Model). Of these, CREAMS (Knisel, 1980) establishes a field model primarily applicable at a scale incorporating hillslope and valley bottom (Rudra et al., 1998), which partially meets requirements for the protection of water resources. At watershed-scale, ANSWERS (Beasley et al., 1980) considers the relationship between non-point source pollution and soil erosion. The individual rain distributed models LIMSEM (De Roo, 1996) and EUROSEM (Morgan et al., 1998) are both physiccally-based. Nevertheless, the mechanism model WEPP (Laflen et al., 1991) released by USDA in 1995 accounts for rainfall infiltration, irrigation, surface runoff, soil separation, sediment transport and deposition process, plant growth and decomposition of residues, and is by far the most complicated calculation model for the prediction of soil erosion. In recent years, several new models based on stochastic theory (Foufoula-Georgiou and Stark, 2010; Chen et al., 2013) and selforganization concept have been applied to the simulation of slope surface erosion (Han et al., 2011) and have the potential to predict rill evolution in detail.

The accurate prediction of water and sediment variations at different temporal and spatial scales is very difficult using the aforementioned models owing to excessively high data requirements and limitations of scale-up. Most conventional methodologies for soil-erosion assessment are limited to small or medium river basins. Although efforts have been made to develop an alternative approach for soil-erosion intensity assessment in large basins (see e.g. Ni et al., 2014), more information about the influencing factors is still needed from systematic field studies.

\section{Sediment and Soil Chemical Transport Processes}

Migration and transformation of soil organic matter and other chemical nutrients occur simultaneously with soil erosion and sediment transport. Such processes can result in decline in soil fertility, reduction in crop yield, and release of chemical components into rivers, lakes or reservoirs, perhaps leading to non-point source pollution and eutrophication. It is generally believed that nutrient loss from surface soil is driven by nutrients becoming dissolved by runoff and/or being carried away through sediment transport. Hitherto, nutrient loss from slope surface soil has mostly been determined from rainfall-runoff plots through real-time monitoring and analysis of runoff, sediment and nutrient. For example, a five-year continuous field observation on the loss of nitrogen due to growth season drainage in the United States, showed that losses by use in the case of fertilizers were 48.8, 96 and $144 \mathrm{~kg}$ nitrogen per hectare, corresponding to 4.8, 9.6 and 12.7 times that obtained for no fertilizer (Almasri and Kaluarachchi, 2004).

Water and sediment are not only the main carriers of other materials but also affect their migration and transformation. During soil erosion and sediment transport, the flow of water and sediment influences the dissolution of inorganic and organic components in sediments as well as the redistribution of external contaminants between solid and liquid phases, e.g. adsorption and desorption (McCulloch et al., 2003).
These can further alter sediment composition and the occurrences of pollutant contamination between the different phases, ultimately affecting the water environment status. Moreover, inorganic components in soil or sediment could also affect the retention of metal species, and further affect their migration behavior through water and sediment transport. Background values of trace elements in sediments directly determine the species and content of various background ions in the water phase, altering the adsorption of organic pollutants onto sediment. Humic organic components in soil or sediment also play an important role in interphase distribution or dissolution, affecting not only water quality but also the adsorption and desorption of organic matter (Grathwohl, 1990; Kile et al., 1995; Luthy et al., 1997).

In flowing water, the presence of sediment also affects biodegradation and photolysis of organic pollutants, leading to their transformation between either liquid and gas or solid and gas phases. It has been reported that sediment can promote the biodegradation of organic pollutants (Xia and Wang, 2008; Duong et al., 2009). Due to the enrichment of various nutrients in sediment particles, the sediment itself provides better conditions for microbial growth. Sediment acts as a carrier for microbial adhesion and metabolic activity, thus encouraging rapid proliferation of microorganisms. Moreover, sediment also transports pollutants and provides direct contact conditions beneficial to microorganisms and organic matter (Marchesi et al., 1994).

Although the degradation of organic matter has been a focus for interaction between water, sediment and pollutants in terms of its impact on water quality and pollutant migration and transformation, such degradation does not necessarily mean complete detoxication and mineralization. For example, organic pollutants such as steroids are by no means completely removed in the degradation process. Instead, they are transformed into other intermediates maintaining a potential ecological hazard; in this context, the presence of sediment may promote further transformation of pollutants. Mineralization (involving $\mathrm{CO}_{2}$ emission) is of key importance in understanding the mechanisms behind migration and transformation of organics in sediment-laden flow, and could serve as a useful indicator for environmental and ecological consequence diagnoses.

\section{Sediment-induced $\mathrm{CO}_{2}$ Emission and Sequestration}

During sediment movement, mineral weathering is most active (Lal, 2003; Berhe et al., 2007), with physical, chemical and biological processes relevant to organic carbon decomposition, synthesis and transformation also affected, leading to $\mathrm{CO}_{2}$ sequestration, emission, and change of concentration in the atmosphere (Stallard, 1998; Smith et al., 2001; Berhe et al., 2007; Quinton et al., 2010).

The three main pathways for $\mathrm{CO}_{2}$ exchange between soil and atmosphere include chemical weathering of minerals in the soil, and the formation and decomposition of soil organic matter (Suchet and Probst, 1995; Van Oost et al., 2007). $\mathrm{CO}_{2}$ 
fixation of inorganic minerals in sediment-laden flow is usually attributed to accelerate chemical weathering via sediment transport. Silicate and carbonate in broken soil particles generate soluble bicarbonate by absorbing $\mathrm{CO}_{2}$ as runoffinduced scouring occurs, creating a "carbon sink" (Meybeck, 1982; Berner et al., 1983; Gaillardet et al., 1999). Although the consensus is that the processes of $\mathrm{CO}_{2}$ sequestration and emission of organic carbon in sediment-laden flow are primarily caused by changes to the behavior of soil organic carbon at different stages of sediment movement, controversy still exists about the exact effect of $\mathrm{CO}_{2}$ emission or sequestration at a specific stage (e.g. erosion, transport or deposition).

In a region of sediment erosion, soil particles undergoing crushing and migration cause organic carbon decomposition to speed up, thus releasing more $\mathrm{CO}_{2}$ (Lal, 1995, 2003; Jenerette and Lal, 2007). Meanwhile, the loss of soil organic carbon during soil erosion helps reduce surface plant growth due to diminished fertility and volume of residues available from fields, resulting in loss of the soil carbon pool (Lal, 1995). An alternative view is that soil formation and $\mathrm{CO}_{2}$ fixation are accelerated due to surface organic carbon loss in an erosion area, resulting in the so-called "substitution effect" (replacement) thereby increasing the storage of the soil carbon pool (Stallard, 1998; Harden et al., 1999; Smith et al., 2001; Harden et al., 2002; McCarty and Ritchie, 2002; Fontaine et al., 2007; Quine and Van Oost, 2007; Van Oost et al., 2007; Quinton et al., 2010).

Soil organic carbon is believed to be further decomposed in areas dominated by sediment transport, though different views exist regarding the decomposition ratio. Smith et al. (2001) used an equilibrium model to point out that the longitudinal decomposition of organic carbon is almost negligible. However, Jacinthe and Lal (2001) found, by interpreting experimental data, that approximately $15 \%$ of soil organic carbon was converted to $\mathrm{CO}_{2}$ in the sediment transport process. Óskarsson et al. (2004) argued that the organic carbon decomposition rate could reach $50 \%$ in the process, and Schlesinger (1995) even reckoned that $100 \%$ soil organic carbon could transform into $\mathrm{CO}_{2}$.

Harden et al. (2002) suggested that upstream sediment entering areas of sediment deposition tends to enrich organic carbon, increasing $\mathrm{CO}_{2}$ decomposition and emission. Other investigators (Stallard, 1998; Berhe et al., 2007) have claimed that a protective layer would form on the original soil due to sediment deposition, hindering subsoil decomposition and reducing the rate of release of $\mathrm{CO}_{2}$. However, the sediment organic carbon content in the protective layer is often lower than that of the carbon-rich original surface soil, and thus the soil balance once again breaks, accelerating $\mathrm{CO}_{2}$ fixation and enhancing storage of the carbon pool (Stallard, 1998; Smith et al., 2001).

In certain countries, including Bangladesh, Brazil, Burma, China, India and the USA, the sediment content of major rivers can be relatively high (e.g. the Amazon, Yellow and Ganges-Brahmaputra all carry a mean sediment load of $\sim 10^{9}$ tons per annum; see e.g. Milliman and Meade, 1983; Goodbred and Kuehl, 2000), and so the process of material fluxes becomes more complicated. For example, substantially different chemical and biological behaviors of inorganic/organic carbon and organic pollutants have been reported for Chinese rivers with high sediment content (Marshall et al., 2000; Xia and Wang, 2008; Duong et al., 2009). To date, almost no research studies have considered the environmental consequences of sediment-laden river flows in terms of $\mathrm{CO}_{2}$ emission and sequestration. This is likely to provide fertile ground for future scientific studies.

Through interaction with carbonate rocks, biophysical and biochemical processes play an important role in the global carbon balance. Biological metabolic processes involve carbonate activation. Biological composition, structure and activity affect (directly or indirectly) the circulation and transformation of soil organic carbon throughout the whole process of sediment movement. Soil microorganisms provide a constantly updated dynamic driver for soil carbon form transfer, which continuously assimilates materials in the environment as part of the microorganisms' metabolic processes while releasing carbon components in different forms to the environment. Until now, there has been no unified understanding about biological effects on the soil carbon pool in sediment erosion regions. In such regions, biological photosynthesis and respiration also cause the content of inorganic carbon in river water to vary, although this may be subject to the influence of sediment content. Moreover, sediment, as a carrier of pollutants and microorganisms, could cause changes to the biological behavior of organic pollutants in water (Marshall et al., 2000; Duong et al., 2009), hence altering rates of $\mathrm{CO}_{2}$ emission and sequestration. In depositional areas, the biological mineralization of soil organic carbon becomes a very complicated process affecting a wide range of parameters, including soil properties, temperature, moisture, and organic carbon composition.

Different degradation rates of soil organic carbon are likely in areas which experience different erosional, transport and depositional processes associated with sediment movement (Berhe, 2012). Obviously, considerable attention should be paid to the influence of biological processes on the carbon cycle, in the overall context of sediment processes.

\section{Dissolved Organic Carbon (DOC)}

In addition to the vertical pathway of exchange of carbon (i.e. $\mathrm{CO}_{2}$ ) between terrestrial ecosystems and the atmosphere, there is also a horizontal pathway of significant soil carbon loss of dissolved organic carbon (DOC) to the riverine environment. The hydrological erosion pathway is more by subsurface flow than by surface runoff, and as such the riverine concentrations of DOC are a function of myriad factors, including climate, season, soil type, ecosystem type, temperature, rainfall, and antecedent soil moisture. While the concentration of DOC is in itself an informant variable, the flux of DOC (i.e. the product of DOC concentration and riverine flow rate) provides greater insight into DOC impact on carbon loss and water quality. The problems associated with DOC in riverine water are three-fold: firstly its carbon loss from soils contri- 
butes to soil quality degradation; secondly, as DOC export is a source term in catchment carbon budgets, increasing DOC loss (export) may result in some catchments (especially peatlands) becoming sources for carbon and thus destabilizing their large soil stores of carbon; and thirdly its negative impact on water quality if high DOC waters are used as the raw water in potable water treatment plants and then treated with chlorine disinfection possibly resulting in elevated levels of carcinogenic trihalomethanes (THMs) and other toxins.

A number of studies have shown that DOC riverine concentrations have been increasing over the past two to three decades, especially over Northern Europe and North America (Evans et al., 2005; Monteith et al., 2007; Grieve and Gilvear, 2008; Sucker and Krause, 2010; Mehring et al., 2013; Tian et al., 2013; Filella and Rodriguez-Murillo, 2014; Oni et al., 2014). Several hypotheses have been tendered as possible explanations for this DOC increase, including: decreasing atmospheric sulphur concentration; climate warming (with seasonal temperature increases); increasing precipitation with increasing annual (e.g. winter/spring) river discharge; reducing summer discharge; longer inter-annual drought length; increasing atmospheric $\mathrm{CO}_{2}$ concentration; $\mathrm{CO}_{2}$ mediated stimulation of primary productivity; increasing decomposition; land-use landmanagement change (e.g. afforestation of peatlands; wind far$\mathrm{m}$ developments and disturbance); catchment scale; and climate zones.

Freeman et al. (2004) in peatland manipulation experiments found that reduced summer precipitation did not explain increases in DOC concentration. Noting increases in atmospheric $\mathrm{CO}_{2}\left(\mathrm{CO}_{2}\right.$ enrichment), they proposed that DOC increases were induced by increased primary production and DOC exudation from plants. Evans et al., (2005), in a study of 22 UK upland waters, found that DOC concentrations increased by an average of $91 \%$ during the previous 15 years and noted that this increase resulted from a combination of declining acid rain deposition (reducing atmospheric sulphur concentration) and rising temperatures. In an assessment of data from 522 remote lakes and streams in North America and Northern Europe, Monteith et al. (2007) found that DOC concentrations increased in proportion to the declining rates of atmospherically-deposited anthropogenic sulphur. Monteith et al. stressed that the rise in DOC concentration was integral to the recovery from acidification. Grieve and Gilvear (2008) in a study of tributaries (disturbed due to wind farm construction on blanket peatlands versus undisturbed) found DOC concentrations to be always higher in the disturbed streams by concentrations ranging between 2 and $5 \mathrm{mg} / \mathrm{L}$. A review by Sucker and Krause (2010) found that the most realistic reason for DOC increases was the complex interaction of changing atmospheric sulphur deposition and climate warming. Clark et al. (2010) observed a stalemate had occurred in the debate as to why DOC increases, between those favoring decreasing atmospheric sulphur deposition and those supporting climate warming. They suggested that the conflicting observations may be due to them being derived from experiments taken at different spatial and temporal scales.

In a review of DOC cycling and transformation in rive- rine and estuarine waters, Bauer and Bianchi (2011) noted that DOC is derived from terrestrial vegetation and soils. Bauer and Bianchi observed that estuaries bordering the Gulf of Mexico have among the highest DOC concentrations as well as the some of the highest rates of fresh litter decomposition. Kindler et al. (2011) found that DOC losses constitute a small but continuous loss of carbon from terrestrial ecosystems, typically of the order of $25 \%$ of net ecosystem exchange and as such must be incorporated in carbon budgets. Laudon et al. (2012) in a study of 49 catchments in Northern latitudes found that the mean annual temperature (MAT), in the range of -3 to $10{ }^{\circ} \mathrm{C}$, has a strong control over regional stream water DOC concentration, with the highest concentrations in regions with mean annual temperature ranging between 0 and $3{ }^{\circ} \mathrm{C}$. Räike et al. (2012) examined 36 years of data from Finland, and reported increases in DOC stream water concentrations but no increase in DOC export. This holds when precipitation and stream flow decreases, possibly due to climate warming. Oni et al. (2013) studied three nested headwater boreal catchments, and found that stream DOC was positively-correlated with certain trace metals (copper, iron and zinc) and negativelycorrelated with several other chemical parameters (sulphate, conductivity, and calcium). These observations indicate the subtle effects of recovery from acidification. However, Oni et al. (2013) concluded that climate warming rather than recovery from acidification could be the dominant driver of DOC increases in the boreal catchments they considered. Mehring et al. (2013) found that long drought periods in North American rivers reduced DOC concentration (in summers) followed by higher DOC concentration in the later hydroperiod (autumn /winter). Tian et al. (2013) observed that a linear relationship held between the surface temperature and mean instream DOC concentration at the annual scale for seven major watersheds, including coastal rivers crossing different climate zones. Their results strongly suggest that climate warming is the primary factor causing the increasing DOC flux. They also note that landscape factors are a secondary consideration.

In a recent study, Koehler et al. (2009) found the concentrations of DOC in peatland stream water in Ireland, ranged from 2.7 to $11.5 \mathrm{mg} / \mathrm{L}$ over one year with the higher concentrations in the summer. The DOC concentrations were highly correlated with temperature. However as the flow rates were much higher in winter, the export of DOC was highest in winter. The annual export of DOC for the year 2007 was $14.1 \mathrm{~g}$ $\mathrm{cm}^{2} \mathrm{ha}^{-1} \mathrm{yr}^{-1}$. This was approximately twice that of the carbon in $\mathrm{CH}_{4}$ emissions and approximately half that of the atmospheric carbon sequestered by the peat soils. Liu et al. (2014) investigated the spatial and seasonal variation of DOC concentrations in 55 Irish streams on seven time occasions over 1 year (2006/2007). The DOC concentrations ranged from 0.9 to $25.9 \mathrm{mg} / \mathrm{L}$ with a mean value of 6.8 and a median value of $5.7 \mathrm{mg} / \mathrm{L}$ and varied significantly over the course of the year. The DOC concentrations from late winter (February: $5.2 \pm 3.0$ $\mathrm{mg} / \mathrm{L}$ across 55 sites) and early spring (April: $4.5 \pm 3.5 \mathrm{mg} / \mathrm{L}$ ) had significantly lower DOC concentrations than autumn (October: mean $8.3 \pm 5.6 \mathrm{mg} / \mathrm{L}$ ) and early winter (December: 8.3 $\pm 5.1 \mathrm{mg} / \mathrm{L})$. Stream runoff from peat soils had the highest 
DOC concentrations and the highest DOC export while the lowest were from catchments with mineral soils (with soil organic matter $(\mathrm{SOM})<3 \%)$. The DOC production sources (e. g., litterfall) or the accumulation of DOC over dry periods might be the driving factor of seasonal change in Irish stream DOC concentrations. Analysis of data using stepwise multiple linear regression techniques identified the topographic index (TI, an indication of saturation-excess runoff potential) and soil conditions (organic carbon content and soil drainage characteristics) as key factors in controlling DOC spatial variation in different seasons. The TI and soil carbon content (e.g., soil organic carbon; peat occurrence) are positively related to DOC concentrations, while well-drained soils are related to DOC concentrations. Similar observations have been noted by Worrall et al. (2006), Worrall and Burt (2007), Eimers et al. (2008), Dawson et al. (2008), and others.

There is growing concern internationally amongst water treatment plant (WTP) operators and water quality (WQ) regulatory agencies with regard to the levels of natural organic matter (NOM) such as DOC present in raw water and persisting in treated water prior to disinfection. The presence of elevated NOM can cause problems in water treatment processes at drinking WTPs and problematic WQ of water when treated with chlorine disinfectant. Problems occur not just as the treated water leaves the WTP but also along the distribution network and more crucially at the consumer's tap. The problems at the WTP include: negative WQ effects on aesthetics, colour, taste and odour; inefficiencies in coagulation/flocculation processes leading to smaller floc sizes and more expensive floc settlement costs; the requirement for activated carbon process (GAC) and the production of elevated levels of trihalomethanes (THMs), haloacetic acids (HAAs) and other toxins in the drinking water (EPA and HSE, 2011; EPA, 2012). Elevated NOMs can lead to the promotion of an unhealthy biological growth in the water distribution network. At the tap, the above issues are integrated, resulting in: poor WQ in colour, taste and odour (including chlorine odour); and elevated THMs and other toxins. Chlorine has a long track record (more than 100 years) of success (USEPA, 1999). THMs are a group of organic chemicals which are considered to be carcinogenic in excessive amounts. EU regulations have an upper limit of $100 \mu \mathrm{g} / \mathrm{L}$ for total THMs, which are composed of the four compounds: Chloroform, Bromoform, Dibromochoromethane, and Bromodichloromethane. Haloacetic acids (HAAs) are a further group of chlorine associated DBPs, receiving more recent attention. The higher the chlorine dose, the higher the THMs (Kraus et al., 2010). The levels of NOM concentration have significant variation on the temporal and spatial scales. Typically NOMs increase in flood events and decrease in low flow periods. While the high river flow seasons of Autumn and Winter are more likely to have highest NOM concentrations, periods of NOM flushing can occur in Spring and Summer flood events (after dry periods). NOMs are thus considered to vary over the seasons and even from year to year, depending on the climate. NOMs are also known to increase with temperature (Koehler et al., 2009) and possibly with climate change. Upland peatland catchments tend to have high NOMs which tend to be diluted in the downstream direction as the catchment size enlarges. However, where rivers flow into lakes, and lakes are used as raw water sources for WTPs, then the low velocity lakes can retain elevated NOM concentrations. Understanding both chemical and physical characteristics of NOM in source waters is key to better water treatment (Wei et al., 2008).

\section{Conclusions}

Modeling of runoff and sediment yield in multiple-scale watersheds remains a challenging problem even though considerable progress has been made on understanding the mechanics of sediment transport from entrainment to deposition. However, the present review highlights new problems that are emerging about the effects of sediment motion, noting increasing environmental and ecological concerns at scales from hillside to global. In a river basin, it is necessary to consider the integrated physical, chemical and biological aspects of sediment flux in order to appreciate the wider impact on the eco-system. The review has shown that it is necessary to consider simultaneously soil erosion, sediment transport and the associated movement of dissolved organic carbon and chemicals, along with horizontal and vertical carbon exchanges. This leads naturally to the concept of a universal flux equation that integrates all the foregoing aspects of sediment flux. More field data are required on soil erosion and carbon exchanges at different spatial scales. Future research effort needs to be directed towards a better understanding of integrated sediment transport processes in multi-phase systems, and their environmental consequences. Our understanding of the biological response to sediment flux needs strengthening particularly in the context of carbon and nitrogen transformations, including sequestration and emission of greenhouse gases accompanied with sediment erosion, transport and deposition. This can only be achieved by a combination of fundamental laboratory-based research into soil-water-sediment science and high quality field observation campaigns conducted in major river basins at sufficient spatial resolution. A relevant example of the former is provided by Wang et al. (2014) who recently measured the soil organic carbon, dissolved organic carbon and $\mathrm{CO}_{2}$ fluxes in a laboratory-scale flume containing loess soil subjected to simulated rainfall.

Acknowledgments. The third-named author undertook part of this study while working on an EU FP7 Marie Curie Actions Project PIRSES-GA-2011-294976 on Geohazards.

\section{References}

Abad, J.D., Buscaglia, G.C., and Garcia, M.H. (2008). 2D stream hydrodynamic, sediment transport and bed morphology model for engineering applications. Hydrol. Process., 22(10), 1443-1459. Http://dx.doi.org/10.1002/hyp.6697

Aich, V., Zimmermann, A., and Elsenbeer, H. (2014). Quantification and interpretation of suspended-sediment discharge hysteresis patterns: How much data do we need?, Catena, 122, 120-129. http:// 
dx.doi.org/10.1016/j.catena.2014.06.020

Almasri, M.N., and Kaluarachchi, J.J. (2004). Assessment and management of long-term nitrate pollution of ground water in agriculture-dominated watersheds. J. Hydrol., 295(1), 225-245. http://dx. doi. org/10.1016/j.jhydrol.2004.03.013

Ananian, A.K., and Gerbashian, E.T. (1965). About the system of equations of the movement of flow carrying suspended matter. $J$. Hydraul. Res., 3(1), 20-30. http://dx.doi.org/10.1080/0022168650 9500077

Bagnold, R.A. (1962). Auto-suspension of transported sediment; Turbidity currents. Proc. of the Royal Society of London, Ser. A, Math. Phys. Sci., 265(1322), 315-319. http://dx.doi.org/10.1098/rspa.196 2.0012

Bai, Y., and Duan, J.G. (2014). Simulating unsteady flow and sediment transport in vegetated channel network. J. Hydrol., 515, 90102. http://dx.doi.org/10.1016/j.jhydrol.2014.04.030

Bakhmeteff, B.A., and Allan, W. (1946). The mechanism of energy loss in fluid friction. Trans. Am. Soc. Civ. Eng., 111(1), 1043-1080.

Bauer J.E., and Bianchi T.S. (2011). Dissolved organic carbon cycling and transformation, in E. Wolanski and D. S. McLusky (Eds), Treatise on Estuarine and Coastal Science, Academic Press, Waltham, 5, 7-67. http://dx.doi.org/10.1016/B978-0-12-374711-2.005 $02-7$

Beasley, D.B., Huggins, L.F., and Monke, E.J. (1980). ANSWERS: A model for watershed planning. Trans. ASAE, 23(4), 938-944. http: //dx.doi.org/10.13031/2013.34692

Berhe, A.A. (2012). Decomposition of organic substrates at eroding vs. depositional landform positions. Plant Soil, 350(1-2), 261-280. http://dx.doi.org/10.1007/s11104-011-0902-z

Berhe, A.A., Harte, J., Harden, J.W., and Torn, M.S. (2007). The significance of the erosion-induced terrestrial carbon sink. Bioscience, 57(4), 337-346. http://dx.doi.org/10.1641/B570408

Berner, R.A., Lasaga, A.C., and Garrels, R.M. (1983). The carbonatesilicate geochemical cycle and its effect on atmospheric carbon dioxide over the past 100 million years. Am. J. Sci., 283(7), 641683. http://dx.doi.org/10.2475/ajs.283.7.641

Buyevich, Y.A. (1990). Hydrodynamics of dispersions including diffusional effects. Arch. Mech., 42(4-5), 429-442.

Chen, D., Sun H.G., and Zhang, Y. (2013). Fractional dispersion equation for sediment suspension. J. Hydrol., 491, 13-22. http://dx. doi.org/10.1016/j.jhydrol.2013.03.031

Cheng, C., Song, Z.Y., Wang, Y.G., and Zhang, J.S. (2013). An approximation of the improved Rouse equation. Appl. Mech. Mater., 256, 2480-2485. http://dx.doi.org/10.4028/www.scientific.net/AMM.25 6-259.2480

Cheung, M.K., Powell, R.L., and McCarthy, M.J. (1996). Sedimentation of noncolloidal bidisperse suspensions. AIChE J., 42(1), 271276. http://dx.doi.org/10.1002/aic.690420125

Clark, J.M., Bottrell, S.H., Evans, C.D., Monteith, D.T., Bartlett, R., Rose, R., Newton, R.J., and Chapman, P.J. (2010). The importance of the relationship between scale and process in understanding long-term DOC dynamics. Sci. Total Environ., 408, 2768-2775. http://dx.doi.org/10.1016/j.scitotenv.2010.02.046

Davis, R.H., and Gecol, H. (1994). Hindered settling function with no empirical parameters for polydisperse suspensions. AIChE J., 40(3), 570-575. http://dx.doi.org/10.1002/aic.690400317

Dawson, J.J.C., Soulsby, C., Tetzlaff, D., Hrachowitz, M., Dunn, S. M., and Malcolm, I.A. (2008). Influence of hydrology and seasonality of DOC exports from three contrasting upland catchments. Biogeochemistry, 90(1), 93-113. http://dx.doi.org/10.1007/s10533008-9234-3

De Roo, A.P.J. (1996). The LISEM project: An introduction. Hydrol. Process., 10(8), 1021-1025. http://dx.doi.org/10.1002/(SICI)10991085(199608)10:8\%3C1021::AID-HYP407\%3E3.0.CO;2-I
Deng, Z.Q., de Lima, J.LM.P., and Jung, H.S. (2008). Sediment transport rate-based model for rainfall-induced soil erosion. Catena, 76 (1), 54-62. http://dx.doi.org/10.1016/j.catena.2008.09. 005

Drew, D.A. (1975). Turbulent sediment transport over a flat bottom using momentum balance. J. Appl. Mech., 42(1), 38-44. http://dx. doi.org/10.1115/1.3423550

Duong, C.N., Schlenk, D., Chang, N.I., and Kim, S.D. (2009). The effect of particle size on the bioavailability of estrogenic chemicals from sediments. Chemosphere, 76(3), 395-401. http://dx.doi.org/ 10.1016/j.chemosphere.2009.03.024

Eimers, M.C., Watmough, S.A., Buttle, J.M., and Dillon, P.J. (2008). Long term trends in DOC concentration: A cautionary note. Biogeochemistry, 87(1), 71-81. http://dx.doi.org/10.1007/s10533-0079168-1

EPA and HSE Ireland (2011). Joint Position Statement: THMs in Drinking Water, EPA, Wexford, Ireland.

EPA Ireland (2012). EPA Drinking Water Guidance on Disinfection By-Products, Advice Note No. 4. Version 2. EPA, Wexford, Ireland.

Evans, C.D., Monteith, D.T., and Cooper, D.M. (2005). Long term increases in surface water DOC: Observations, possible causes and environmental impact. Environ. Pollut., 137(1), 55-71. http://dx. doi.org/10.1016/j.envpol.2004.12.031

Filella, M., and Rodriguez-Murillo, J.C. (2014). Long term trends of organic carbon concentrations in freshwaters: Strengths and weaknesses of existing evidence. Water, 6(5), 1360-1418. http://dx.doi. org $/ 10.3390 /$ w6051360

Fontaine, S., Barot, S., Barré, P., Bdioui, N., Mary, B., and Rumpel, C. (2007). Stability of organic carbon in deep soil layers controlled by fresh carbon supply. Nature, 450(7167), 277-280. http://dx.doi. org/10.1038/nature06275

Foufoula-Georgiou, E., and Stark, C. (2010). Introduction to special section on stochastic transport and emergent scaling on Earth's surface: Rethinking geomorphic transport-stochastic theories, broad scales of motion and nonlocality. J. Geophys. Res. (F Earth Surf.), 115(F2), F00A01, http://dx.doi.org/10.1029/2010JF001661

Francke, T., López Tarazón, J.A., and Schröder, B. (2008). Estimation of suspended sediment concentration and yield using linear models, random forests and quantile regression forests. Hydrol. Process., 22(25), 4892-4904. http://dx.doi.org/10.1002/hyp.7110

Freeman, C., Fenner, N., Ostle, N.J., Kang, H., Dowrick, D.J., Reynolds, B., Lock, M.A., Sleep, D., Hughes, S., and Hudson, J. (200 4). Export of dissolved organic carbon from peatlands under elevated carbon dioxide levels. Nature, 430(6996), 195-198. http://dx. doi.org/10.1038/nature02707

Gaillardet, J., Dupré, B., Louvat, P., and Allègre, C.J. (1999). Global silicate weathering and $\mathrm{CO}_{2}$ consumption rates deduced from the chemistry of large rivers. Chem. Geol., 159(1), 3-30. http://dx.doi. org/10.1016/S0009-2541(99)00031-5

Galy, V., France-Lanord, C., Beyssac, O., Faure, P., Kudrass, H., and Palhol, F. (2007). Efficient organic carbon burial in the Bengal fan sustained by the Himalayan erosional system. Nature, 450(7168), 407-U6. http://dx.doi.org/10.1038/nature06273

Ganju, N.K., and Schoellhamer, D.H. (2009). Calibration of an estuarine sediment transport model to sediment fluxes as an intermediate step for robust simulation of geomorphic evolution. Cont. Shelf Res., 29(1), 148-158. http://dx.doi.org/10.1016/j.csr.2007.09. 005

Gao, P., and Puckett, J. (2012). A new approach for linking eventbased upland sediment sources to downstream suspended sediment transport. Earth Surf. Process. Landforms, 37(2), 169-179. http:// dx.doi.org/10.1002/esp.2229

Goodbred, S.L., and Kuehl, S.A. (2000). Enormous Ganges-Brahmaputra sediment discharge during strengthened early Holocene mon- 
soon. Geology, 28(12), 1083-1086. http://dx.doi.org/10.1130/0091613(2000)28\%3C1083:EGSDDS\%3E2.0.CO;2

Grathwohl, P. (1990). Influence of organic matter from soils and sediments from various origins on the sorption of some chlorinated aliphatic hydrocarbons: Implications on Koc correlations. Environ. Sci. Technol., 24(11), 1687-1693. http://dx.doi.org/10.1021/es00 $081 \mathrm{a} 010$

Grieve, I., and Gilvear, D. (2008). Effects of wind farm construction on concentrations and fluxes of dissolved organic content and suspended sediment from peat catchments at Braes of Doune, central Scotland. Mires Peat, 4, Art. 3 (Online: http://www.mires-andpeat.net/pages/volumes/map04/map0403.php)

Han, P., Ni, J., Hou, K., Miao, C., and Li, T. (2011). Numerical modeling of gravitational erosion in rill systems. Inter. J. Sed. Res. 26(4), 403-415. http://dx.doi.org/10.1016/S1001-6279(12)60001-8

Harden, J.W., Fries, T.L., and Pavich, M.J. (2002). Cycling of beryllium and carbon through hillslope soils in Iowa. Biogeochemistry, 60(3), 317-336. http://dx.doi.org/10.1023/A:102 0308729553

Harden, J.W., Sharpe, J.M., Parton, W.J., Ojima, D.S., Fries, T.L., Huntington, T.G., and Dabney, S.M. (1999). Dynamic replacement and loss of soil carbon on eroding cropland. Global Biogeochem. Cycles, 13(4), 885-901. http://dx.doi.org/10.1029/1999GB900061

Hunt, J.N. (1954). The turbulent transport of suspended sediment in open channels. Proc. of the Royal Society of London, Ser. A, Math. Phys. Sci., 224(1158), 322-335. http://dx.doi.org/10.1098/rspa.195 4.0161

Itakura, T., and Kishi, T. (1980). Open channel flow with suspended sediments. J. Hydraul. Div., 106(8), 1325-1343.

Iwata, T., Suzuki, T., Togashi, H., Koiwa, N., Shibata, H., and Urabe, J. (2013). Fluvial transport of carbon along the river-to-ocean continuum and its potential impacts on a brackish water food web in the Iwaki River watershed, northern Japan. Ecol. Res., 28(5), 703716. http://dx.doi.org/10.1007/s11284-013-1047-8

Jacinthe, P.A., and Lal, R. (2001). A mass balance approach to assess carbon dioxide evolution during erosional events. Land Degrad. Dev., 12(4), 329-339. http://dx.doi.org/10.1002/ldr.454

Jenerette, G.D., and Lal, R. (2007). Modeled carbon sequestration variation in a linked erosion-deposition system. Ecol. Model., 200(1), 207-216. http://dx.doi.org/10.1016/j.ecolmodel.2006.07.02 7

Kabir, M.A., Dutta, D., and Hironaka, S. (2014). Estimating sediment budget at a river basin scale using a process-based distributed modelling approach. Water Resour. Manage., 28(12), 4143-4160. http: //dx.doi.org/10.1007/s11269-014-0734-8

Kile, D.E., Chiou, C.T., Zhou, H., Li, H., and Xu, O. (1995). Partition of nonpolar organic pollutants from water to soil and sediment organic matters. Environ. Sci. Technol., 29(5), 1401-1406. http:// dx.doi.org/10.1021/es00005a037

Kindler, R., Siemens, J., Kaiser, K., Walmsley, D.C., Bernhofer, C., Buchmann, N., Cellier, P., Eugster, W., Gleixner, G., Grũnwald, T., Heim, A., Ibrom, A., Jones, S.K., Jones, M., Klumpp, K., Kutsch, W., Larsen, K.S., Lehuger, S., Loubet, B., Mckenzie, R., Moors, E., Osborne, B., Pilegaard, K., Rebmann, C., Saunders, M., Schmidt, M.W.I., Schrumpf, M., Seyfferth, J., Skiba, U., Soussana, J.F., Sutton, M.A., Tefs, C., Vowinckel, B., Zeeman, M.J., and Kaupenjohann, M. (2011). Dissolved carbon leaching from soil is a crucial component of the net ecosystem carbon balance. Global Change Biol., 17(2), 1167-1185. http://dx.doi.org/10.1111/j.1365-2486.201 $0.02282 . \mathrm{x}$

Kisi, O., Akbari, N., Sanatipour, M., Hashemi, A., Teimourzadeh, K., and Shiri, J. (2013). Modeling of dissolved oxygen in river water using artificial intelligence techniques. J. Environ. Inf., 22(2), 92101. http://dx.doi.org/10.3808/jei.201300248

Knapp, R.T. (1938). Energy-balance in stream-flows carrying suspended load. Trans. Am. Geophys. Union, 19(1), 501-505. http://dx.
doi.org/10.1029/TR019i001p00501

Knisel, W.G. (1980). CREAMS: A Field Scale Model for Chemicals, Runoff and Erosion from Agricultural Management Systems, USDA, Conservation Research Report No. 26, Washington, DC, pp. 643.

Koehler, A.K., Murphy K., Kiely, G., and Sottocornola, M. (2009). Seasonal variation of DOC concentration and annual loss of DOC from an Atlantic blanket bog in South Western Ireland. Biogeochemistry, 95(2-3), 231-242. http://dx.doi.org/10.1007/s10533-00 9-9333-9

Kraus, T.E.C., Anderson, C.A., Morgenstern, K., Downing, B.D., Pellerin, B.A., and Bergamaschi, B.A. (2010). Determining sources of dissolved organic carbon and disinfection byproduct precursors to the McKenzie River, Oregon. J. Environ. Qual., 39(6), 2100-21 12. http://dx.doi.org/10.2134/jeq2010.0030

Kundu, S., and Ghoshal, K. (2014). Explicit formulation for suspended concentration distribution with near-bed particle deficiency. Powder Technol., 253, 429-437. http://dx.doi.org/10.1016/j.powtec. 2013.11.032

Laflen, J.M., Lane, L.J., and Foster, G.R. (1991) WEPP: A new generation of erosion prediction technology. J. Soil Water Conserv., 46, 34-38.

Lal, R. (1995). Global soil erosion by water and carbon dynamics, in R. Lal, J. Kimble, E. Levine, and B. A. Stewart (Eds), Soils and Global Change, CRC/Lewis Publishers, Boca Raton, FL, USA, pp. 131-142.

Lal, R. (2003). Soil erosion and the global carbon budget. Environ. Int., 29(4), 437-450. http://dx.doi.org/10.1016/S0160-4120(02)00 $192-7$

Lane, E.W., and Kalinske, A.A. (1941). Engineering calculations of suspended sediment. Trans. Am. Geophys. Union, 22(3), 603-607. http://dx.doi.org/10.1029/TR022i003p00603

Laudon, H., Buttle, J., Carey, S.K., McDonnell, J., McGuire, K., Seibert, J., Shanley, J., Soulsby, C., and Tetzlaff, D. (2012). Crossregional prediction of long-term trajectory of stream water DOC response to climate change. Geophys. Res. Lett., 39(18), L18404, http://dx.doi.org/10.1029/2012GL053033

Laursen, E.M. (1980) A concentration distribution formula from the revised theory of Prandtl mixing length, Proc. of First International Conference on River Sedimentation, Guanghua Press, Beijing, pp. 237-244.

Lenzi, M.A., and Marchi, L. (2000). Suspended sediment load during floods in a small stream of the Dolomites (northeastern Italy). Catena, 39(4), 267-282. http://dx.doi.org/10.1016/S0341-8162(00) 00079-5

Liu, W., Xu, X., McGoff, N.M., Eaton, J.M., Leahy, P., Foley, N., and Kiely, G. (2014) Spatial and seasonal variation of dissolved organic carbon (DOC) concentrations in Irish streams: Importance of soil and topography characteristics. Environ. Manage., 53, 959967. http://dx.doi.org/10.1007/s00267-014-0259-1

Luthy, R.G., Aiken, G.R., Brusseau, M.L., Cunningham, S.D., Gschwend, P.M., Pignatello, J.J., Reinhard, M., Traina, S.J., Weber, W.J., and Westall, J.C. (1997). Sequestration of hydrophobic organic contaminants by geosorbents. Environ. Sci. Technol., 31(12), 3341-3347. http://dx.doi.org/10.1021/es970512m

Marchesi, J.R., Owen, S.A., White, G.F., House, W.A., and Russell, N.J. (1994). SDS-degrading bacteria attach to riverine sediment in response to the surfactant or its primary biodegradation product dodecan-1-ol. Microbiology, 140(11), 2999-3006. http://dx.doi.org/ 10.1099/13500872-140-11-2999

Marshall, S.J., House, W.A., and White, G.F. (2000). Role of natural organic matter in accelerating bacterial biodegradation of sodium dodecyl sulfate in rivers. Environ. Sci. Technol., 34(11), 2237-2242. http://dx.doi.org/10.1021/es990828p 
Marttila, H., and Kløve, B. (2010). Dynamics of erosion and suspended sediment transport from drained peatland forestry. J. Hydrol., 388(3), 414-425. http://dx.doi.org/10.1016/j.jhydrol.2010.05.026

Matalas, N.C. (1970). Introduction to random walk and its application to open channel flow, in C. L. Chiu (Ed), Stochastic Hydraulics, pp. 56-65.

McCarty, G.W., and Ritchie, J.C. (2002). Impact of soil movement on carbon sequestration in agricultural ecosystems. Environ. Pollut., 116(3), 423-430. http://dx.doi.org/10.1016/S0269-7491(01)002196

McCulloch, M., Fallon, S., Wyndham, T., Hendy, E., Lough, J., and Barnes, D. (2003). Coral record of increased sediment flux to the inner Great Barrier Reef since European settlement. Nature, 421 (6924), 727-730. http://dx.doi.org/10.1038/nature01361

McTigue, D.F. (1981). Mixture theory for suspended sediment transport. J. Hydraul. Div. ASCE, 107(6), 659-673.

Mehring, A.S., Lowrance, R.R., Helton, A.M., Pringle, C.M., Thompson, A., Bosch, D.D., and Vellidis, G. (2013). Interannual drought length governs dissolved organic carbon dynamics in blackwater rivers of the western upper Suwanee River basin. J. Geophys. Res. (G Biogeosci.), 118, 1-10. http://dx.doi.org/10.1002/2013JG00241 5

Mendoza, C., and Zhou, D. (1995). A dynamic approach to sedimentladen turbulent flows. Water Resour. Res., 31(12), 3075-3087. http: //dx.doi.org/10.1029/95WR02493

Meybeck, M. (1982). Carbon, nitrogen, and phosphorus transport by world rivers. Am. J. Sci., 282(4), 401-450. http://dx.doi.org/10.247 5/ajs.282.4.401

Miller, R.B., Fox, G.A., Penn, C.J., Wilson, S., Parnell, A., Purvis, R. A., and Criswell, K. (2014). Estimating sediment and phosphorus loads from streambanks with and without riparian protection. Agric., Ecosyst. Environ., 189, 70-81. http://dx.doi.org/10.1016/j.age e.2014.03.016

Milliman, J.D., and Meade, R.H. (1983). World-wide delivery of river sediments to the oceans. J. Geol., 91(1), 1-21. http://dx.doi. org $/ 10.1086 / 628741$

Monteith, D.T., Stoddard, J.L., Evans, C.D., Heleen, A., Forsius, M., Høgåsen, Wilander, A., Skjelkvale, B.L., Jeffries, D.S., Vuorenmaa, J., Keller, B., Kopácek, J., and Vesely, J. (2007). Dissolved organic carbon trends resulting from changes in atmospheric deposition chemistry. Nature, 450, 537-541. http://dx.doi.org/10.1038/nature 06316

Mora, A., Laraque, A., Moreira-Turcq, P., and Alfonso, J.A. (2014) Temporal variation and fluxes of dissolved and particulate organic carbon in the Apure, Caura and Orinoco rivers, Venezuela. J. South Am. Earth Sci., 54, 47-56. http://dx.doi.org/10.1016/j.jsames.2014. 04.010

Morgan, R.P.C., Quinton, J.N., Smith, R.E., Govers, G., Poesen, J.W.A., Auerswald, K., Chisci, G., Torri, D., and Styczen, M.E. (1998). The European Soil Erosion Model (EUROSEM): A dynamic approach for predicting sediment transport from fields and small catchments. Earth Surf. Process. Landforms, 23(6), 527-544. http://dx.doi.org/10.1002/(SICI)1096-9837(199806)23:6\%3C527:: AID-ESP868\%3E3.0.CO;2-5

Ni, J.R., and Wang, G.Q. (1991). Vertical sediment distribution. J. Hydraul. Eng. ASCE, 117(9), 1184-1194. http://dx.doi.org/10. 1061/(ASCE)0733-9429(1991)117:9(1184)

Ni, J.R., Wu, A., Li, T.H., Yue, Y., and Borthwick, A. (2014). Efficient soil loss assessment for large basins using smart coded polygons. J. Environ. Inf., 23(2), 47-57. doi:10.3808/jei.201400264

Oni, S.K., Futter, M.N., Teutschbein, C., and Laudon, H. (2014). Cross-scale ensemble predictions of dissolved organic carbon dynamics in boreal forest streams. Clim. Dyn., 42(9-10), 2305-2321. http://dx.doi.org/10.1007/s00382-014-2124-6
Óskarsson, H., Arnalds, Ó., Gudmundsson, J., and Gudbergsson, G. (2004). Organic carbon in Icelandic Andosols: Geographical variation and impact of erosion. Catena, 56(1), 225-238. http://dx.doi. org/10.1016/j.catena.2003.10.013

Panagopoulos, I., Mimikou, M., and Kapetanaki, M. (2007). Estimation of nitrogen and phosphorus losses to surface water and groundwater through the implementation of the SWAT model for Norwegian soils. J. Soils Sed., 7(4), 223-231. http://dx.doi.org/10.106 5/jss2007.04.219

Provansal, M., Dufour, S., Sabatier, F., Anthony, E.J., Raccasi, G., and Robresco, S. (2014). The geomorphic evolution and sediment balance of the lower Rhône River (southern France) over the last 130 years: Hydropower dams versus other control factors. Geomorphology, 219, 27-41. http://dx.doi.org/10.1016/j.geomorph.20 14.04.033

Quine, T.A., and Van Oost, K. (2007). Quantifying carbon sequestration as a result of soil erosion and deposition: Retrospective assessment using caesium-137 and carbon inventories. Global Change Biol., 13(12), 2610-2625. http://dx.doi.org/10.1111/j.13652486.2007.01457.x

Quinton, J.N., Govers, G., Van Oost, K., and Bardgett, R.D. (2010). The impact of agricultural soil erosion on biogeochemical cycling. Nature Geosci., 3(5), 311-314. http://dx.doi.org/10.1038/ngeo838

Räike A., Kortelainen P., Mattsson T., and Thomas D.N. (2012). 36 year trends in dissolved organic carbon export from Finnish rivers to the Baltic Sea. Sci. Total Environ., 435-436, 188-201. http://dx. doi.org/10.1016/j.scitotenv.2012.06.111

Rasteiro, M.G., Figueiredo, M.M., Maia, M.C., and Scarlett, B. (1993). Modelling of solid/liquid flow in pipes. Powder Handl. Process., 5(3), 253.

Raymond, P.A., and Bauer, J.E. (2001). Riverine export of aged terrestrial organic matter to the North Atlantic Ocean. Nature, 409 (68 19), 497-500. http://dx.doi.org/10.1038/35054034

Renard, K.G., Foster, G.R., Weesies, G.A., and Porter, J.P. (1991) RUSLE: Revised universal soil loss equation. J. Soil Water Conserv., 46, 30-33.

Rouse, H. (1937). Modern conceptions of the mechanics or fluid turbulence. Trans. Am. Soc. Civ. Eng., 102(1), 463-505.

Rudra, R.P., Dickinson, W.T., and Wall, G.J. (1998). Problems involving the use of soil erosion models, in J. Boardman and D. FavisMortlock (Eds.), Modelling Soil Erosion by Water, NATO ASI Series, Vol I, 55, Springer-Verlag, Berlin.

Sammori, T., Yusop, Z., Kasran, B., Noguchi, S., and Tani, M. (2004). Suspended solids discharge from a small forested basin in the humid tropics. Hydrol. Process., 18(4), 721-738. http://dx.doi.org/10. 1002/hyp.1361

Schlesinger, W.H. (1995). Soil respiration and changes in soil carbon stocks, in G. M. Woodwell et al. (Eds.), Biotic Feedbacks in the Global Climatic System: Will the Warming Feed the Warming?, New York: Oxford University Press, pp. 159-168.

Smith, S.V., Renwick, W.H., Buddemeier, R.W., and Crossland, C.J. (2001). Budgets of soil erosion and deposition for sediments and sedimentary organic carbon across the conterminous United States. Global Biogeochem. Cycles, 15(3), 697-707. http://dx.doi.org/10. 1029/2000GB001341

Stallard, R.F. (1998). Terrestrial sedimentation and the carbon cycle: Coupling weathering and erosion to carbon burial. Global Biogeochem. Cycles, 12(2), 231-257. http://dx.doi.org/10.1029/98GB007 41

Suchet, P.A., and Probst, J. (1995). A global model for present-day atmospheric/soil $\mathrm{CO}_{2}$ consumption by chemical erosion of continental rocks (GEM-CO ${ }_{2}$ ). Tellus (B Chem. Phys. Meteorol.), 47 (12), 273-280. http://dx.doi.org/10.1034/j.1600-0889.47.issue1.23.x

Sucker C., and Krause K. (2010). Increasing dissolved organic car- 
bon concentrations in freshwaters: What is the actual driver?, iForest J. Biogeosci. For., 3, 106-108. http://dx.doi.org/10.3832/ifor 0546-003

Thouvenot, M., Billen, G., and Garnier J. (2007). Modelling nutrient exchange at the sediment-water interface of river systems. J. Hydrol., 341(1-2), 55-78. http://dx.doi.org/10.1016/j.jhydrol.2007.05. 001

Tian, Y.Q., Yu, Q., Feig, A.D., Ye, C., and Blunden, A. (2013). Effects of climate and land-surface processes on terrestrial dissolved organic carbon export to major U.S. coastal rivers. Ecol. Eng., 54, 192201. http://dx.doi.org/10.1016/j.ecoleng.2013.01.028

Toone, J., Rice, S.P., and Piégay, H. (2014). Spatial discontinuity and temporal evolution of channel morphology along a mixed bedrock-alluvial river, upper Drôme River, southeast France: Contingent responses to external and internal controls. Geomorphology, 205, 5-16. http://dx.doi.org/10.1016/j.geomorph.2012.05.033

Oni S.K., Futter M.N., Bishop K., Köhler S., Ottosson-Löfvenius M., and Laudon H. (2013). Long-term patterns in dissolved organic carbon, major elements and trace metals in boreal headwater catchments: trends, mechanisms and heterogeneity. Biogeosciences. 10(4), 23 15-2330. http://dx.doi.org/10.5194/bg-10-2315-2013.

USEPA (1999). 25 Years of the Safe Drinking Water Act: History and Trends, EPA-816-R-99-007, United States Environmental Protection Agency, Office of Water (4606), USA.

Van Oost, K., Quine, T.A., Govers, G., De Gryze, S., Six, J., Harden, J.W., Ritchie, J.C., McCarty, G.W., Heckrath, G., Kosmas, C., Giraldez, J.V., Marques da Silva, J.R., and Merckx, R. (2007). The impact of agricultural soil erosion on the global carbon cycle. Science, 318(5850), 626-629. http://dx.doi.org/10.1126/science.11 45724

Van Rijn, L.C., Ribberink, J.S., Van Der Werf, J., and Walstra, D.J.R. (2013). Coastal sediment dynamics: Recent advances and future research needs. J. Hydraul. Res., 51(5), 475-493. http://dx.doi.org/
10.1080/00221686.2013.849297

Wang, X., Cammeraat, E.L.H., Romeijn, P., and Kalbitz, K. (2014). Soil organic carbon redistribution by water erosion-the role of $\mathrm{CO}_{2}$ emissions for the carbon budget. PLOS ONE, 9(5), e96299. http:// dx.doi.org/10.1371/journal.pone.0096299

Wei, Q., Wang, D., Wei, Q., Qiao, C., Shi, B., and Tang, H. (2008). Size and resin fractionations of dissolved organic carbon and trihalomethane precursors from four typical source waters in China. Environ. Monit. Assess., 141(1-3), 347-357. http://dx.doi.org/10.1 007/s10661-007-9901-1

Wischmeier, W.H. (1976). Use and misuse of the Universal Soil Loss Equation. J. Soil Water Conserv., 31(1), 5-9.

Worrall, F., Burt, T.P., and Adamson, J.K. (2006). Long term changes in hydrological pathways in an upland peat catchment-recovery from drought?, J. Hydrol., 321(1-4), 5-20. http://dx.doi.org/10.10 16/j.jhydrol.2005.06.043

Worrall, F., and Burt, T.P. (2007). Trends in DOC concentration in Great Britain. J. Hydrol., 346(1-2), 81-92. http://dx.doi.org/10.101 6/j.jhydrol.2007.08.021

Xia, X., and Wang, R. (2008). Effect of sediment particle size on polycyclic aromatic hydrocarbon biodegradation: Importance of the sediment-water interface. Environ. Toxicol. Chem., 27(1), 119-125. http://dx.doi.org/10.1897/06-643

Xue, B., and Sun, Y. (2003). Modeling of sedimentation of polydisperse spherical beads with a broad size distribution. Chem. Eng. Sci., 58(8), 1531-1543. http://dx.doi.org/10.1016/S0009-2509(02) 00656-5

Zagustin, K. (1968). Sediment distribution in turbulent flow. J. Hydraul. Res., 6(2), 163-172. http://dx.doi.org/10.1080/00221686809 500227

Zhang, S.Y., Duan J.G., and Strelkoff, T.S. (2013). Grain-scale nonequilibrium sediment-transport model for unsteady flow. ASCE $J$. Hydraul. Eng., 139(1), 22-36. http://dx.doi.org/10.1061/(ASCE)H Y.1943-7900.000064 